\title{
REVISITING THE TRIPLE BOTTOM LINE
}

\author{
RAINE ISAKSSON \\ Uppsala University, Engineering Sciences, Sweden
}

\begin{abstract}
Sustainable development has been on global agendas for more than 30 years. Important improvements in reducing pollution and improving social conditions have been achieved in many countries. However, on the global level, human activities are highly unsustainable, exemplified with the fact that humanity needs the production of 1.7 planets for its yearly consumption. Corporate Social Responsibility (CSR) could be viewed as sustainable development for companies and organisations. CSR is frequently described with the Triple Bottom Line (TBL), often presented as Profit, People and Planet. The interpretation of the TBL could be difficult with challenges being such as what should be reported and how the three dimensions could be reconciled. Over time there has been a change shifting some of the focus from Profit to firstly Planet and then later on People. Defining Profit as part of CSR could be a challenge. Is profit maximisation part of CSR? Should all financial reporting be part of sustainability reporting or only the value created for all stakeholders? This paper discusses CSR from a stakeholder needs perspective and which effects this could have on sustainability indicators and the elements of the TBL. The preliminary results indicate that a paradigm shift is needed where this means that focus is moved from Profit to People and Planet. Parallel to the Quality Management strategy of customer focus as a way to create profit, stakeholder needs focus is proposed as a new strategy. Profit should be seen as a means to an end. Sustainability should be assessed in the entire company value chain. Integrated reporting including standard financial reporting is viewed as questionable. Reporting of Profit is proposed to focus on reporting value created for all stakeholders with focus on stakeholder needs.

Keywords: sustainability, triple bottom line, economic sustainability, agenda 2030, CSR, value per harm, quality management
\end{abstract}

\section{INTRODUCTION}

Sustainable development has been on global agendas for more than 30 years. Most branches and many developed nations have achieved important improvements. However, on the global level human activities are highly unsustainable, exemplified with the fact that humanity needs the production of 1.7 planets for its yearly consumption [1]. Global warming is another sign of non-sustainability, where nations, companies and individuals need to accelerate change towards a level of sustainability.

Companies play an important role in sustainable development. Corporate Social Responsibility (CSR) could be viewed as organisational sustainable development. Companies often manage their sustainability performance using the Triple Bottom Line logic (TBL) that presents a win-win-win logic with focus on Profit, People and Planet [2]-[4]. The TBL forms an important structure for managing sustainability. Sustainability reporting is an important part of sustainability management. Reporting demonstrates to the interested reader how the company performs in terms of sustainability and how they are working with improvements. The Global Reporting Initiative guidelines, which recently have been converted into standards, are largely based on the TBL concept [5]. The guidelines have been available for almost 20 years without seemingly solving the problem of how to clearly define sustainability priorities and how to reconcile the different dimensions. The GRI standards suggest the content for Profit, People and Planet. For Profit the main indicator is: "Disclosure 201-1 Direct economic value generated and distributed", which presents economic sustainability in terms of sales value [5]. There is little customer needs focus and the underlying assumption is that user value can be assessed in sales value only. There have been 
suggestions on looking at customer and stakeholder value as part of value creation [6], [7]. The GRI standards provide indication of what should be reported for Profit, People and Planet but the question of priority will be decided in the company materiality analysis. GRI describes materiality as: "The report shall cover topics that reflect the reporting organization's significant economic, environmental, and social impacts; or (that) substantively influence the assessments and decisions of stakeholders" [8]. The reporting company can to some extent choose what to report as significant sustainability impacts.

The GRI proposes the sustainability context as: "The organization describes how economic, environmental, and/or social topics relate to its long-term strategy, risks, opportunities, and goals, including in its value chain" [9]. In spite of this companies reporting according to the standards still can opt to focus on only accounting for the direct company footprint for e.g. water or carbon dioxide. As an example Coca Cola European Partners says in their Stakeholder Progress report that they use 1.61 litres per litre of drink [10]. This is only for the internal use and not for the value chain where the total water footprint is about 70 litres/litre of drink. The information of the total water footprint can be found implicitly but requires very careful reading. A similar example can be found among the tree largest Swedish food retailers Axfood, Coop and ICA that all report a relatively low carbon footprint, but which only includes the footprint from internal transports and energy consumption in shops and excludes agriculture among other things. The food retailer Coop declares that they provide a sales value of about 100000 Euro per ton of carbon dioxide [11]. Since food in Sweden stands for about 2.5 tons of $\mathrm{CO}_{2} /$ person and year based on consumption it is easy to calculate that the reported figures only account for about $2.5 \%$ of the carbon emissions in the value chain. From the perspective of the responsible user who wants to make a sustainable choice it is similar to receiving price information where the cost of purchase is excluded. Logically the company that sells and promotes a particular product could be seen to be responsible for driving the footprints in the entire value chain.

When defining what should be reported an important point is to view effects on stakeholders in the entire value chain or supply chain [12]. The first challenge in good sustainability reporting is what to report. The second challenge is how to measure performance using the TBL to produce adequate performance management. Several authors have noted that measuring the TBL is not easy [13]-[16]. This could consist a severe problem for managing sustainability. Important issues are both what should be measured for Profit, People and Planet and how to reconcile the three dimensions for effectively managing sustainability?

During the 20 years since the launching of the idea of TBL the interpretation of the different dimensions and their relation seems to change. There appears to be a shift from a very strong focus on Profit towards an additional and increased focus on Planet and more lately also on People [17]. There is an increasing understanding of how human activities affect the state of the planet as described in the Planetary Boundaries [18]. This means that the "what to report" in the Planet dimension, when converted into company goals should reflect the outer system limits. This is exemplified with the Science Based Targets initiative that suggests how to set carbon targets relating to external requirements [19]. A similar logic of externally set targets could be employed for other Planetary Boundaries. Haffar and Searcy note in studying Canadian leading companies that sustainability targets in most studied sustainability reports still are "organisation centric" targets [20]. Companies have as their starting point the current situation and then work with a forecast based on what is seen as reasonable improvement from the starting point. The problem is that when most companies do this the rate of improvement might not be enough to achieve sustainable development. Instead the logic of The Natural Step and Backasting might have to be employed [21]. 
Backasting starts with setting a sustainable goal and then compares that with the current situation in order to find the best way forwards [22]. This implies that it is important to visualise how a sustainable future will look like. In this work the UN Sustainable Development Goals (SDG) should be of good support. For many of the 17 goals it could be challenging to set numeric targets. For goal 13 - climate change - this should be doable. It could be argued that out of the planetary boundaries' climate change is one of the most important and one, which has bearing on basically all companies. Based on the Paris agreement from 2015 of limiting global warming to less than $2{ }^{\circ} \mathrm{C}$ it is possible to set a numeric target for how the level of sustainability looks like. Managing carbon emission and climate could be used as an indicator that exemplifies the level of management of the Planet dimension highlighting both the "what" and the "how".

The first Sustainable Development Goal is: No Poverty. It could be argued that at the level of People needs this is a factor that is among the most important having effects on other important indicators such as hunger, health, and schooling. For poverty like for climate it should be possible to set numeric targets. Most companies work in supply chains that include many companies, out of which some could be based in developing countries struggling with poverty. This indicates that poverty, like climate could be an issue for most companies.

There seems to be limited discussion on what Profit is in terms of sustainability. There are suggestions on working with value adding by converting waste into user value [23]. Value compared to harm is discussed in e.g. Eco Efficiency where sales value is compared with footprints [24]. Value in the GRI standards is defined as sales value and the distribution of it to different stakeholder such as employees and society. What a sustainable level for Profit is constitutes a theoretical challenge. In Creating Shared Value (CSV) focus is on increasing the total value adding seeing that all stakeholders get an increased share [25], [26]. This goes beyond what is indicated by GRI indicators that focus on distribution of a fixed value. In a sustainability context the question could be asked who the main stakeholder are. Seeing Profit in terms of stakeholder value creation compared to footprints is done in some articles e.g. [6], [27], [28]. Based on the Brundtland commission definition of sustainable development it could be argued that focus is primarily on People, which implies also focus on Planet [27].

Generally it should be possible, based on the ideas of Back casting, to define a visionary sustainable state expressed for all of the three dimensions of the Triple Bottom Line. Using a combination of absolute and relative indicators could possibly provide a solution for combing TBL indicators. This proposed visionary state could then be compared with the actual situation in order to provide companies with the input needed for designing a roadmap towards a state of sustainability.

The purpose of this paper is to highlight challenges with The Triple Bottom Line in defining what to identify as important impacts, how to measure and how to set targets. A particular focus is on highlighting Profit as stakeholder needs value. The following research questions have been formulated:

RQ1: How could visionary performance levels of Profit, People and Planet be described based on stakeholder focus needs?

RQ2: How could TBL performance be measured?

\section{METHOD}

A review of definitions of the Triple Bottom Line generally and of the economic dimensions specifically has been carried out using the database Google Scholar. Setting of a sustainability vision based on the TBL is based on inductive work. The works started from the common definition of CSR seen as activities, which are done in addition to what is required by laws and regulations. Focus was on defining sustainability for People and Planet based on a Pareto- 
approach or the 20:80 rule, limiting the number of sustainability impacts studied to one in each dimension. The first delimitation is that for People where the visionary description is based on the Sustainable Development Goal (SDG) No 1 - No Poverty. The second delimitation is that for Planet the visionary description is based on SDG No 13 - Climate Action. The target level in 2030 for the carbon emissions was calculated based on the "Carbon Law" [29]. Profit is defined as sales value [5] and in terms of stakeholder value creation. The shareholder value is assumed to be at a reasonable budgeted level and was not further studied. Instead focus was on the stakeholder value creation based on contribution to poverty reduction in comparison with carbon footprint as harm. This is based on the general logic of user value per planet harm [27]. The visionary state was described using both absolute and relative indicators. The description is presented as a matrix with visionary indications for the different dimensions and for relative performance.

\section{HOW COULD VISIONARY PERFORMANCE LEVELS OF PROFIT, PEOPLE AND PLANET BE DESCRIBED BASED ON STAKEHOLDER FOCUS NEEDS?}

This section presents results from the discussion on the TBL and the TBL-dimensions.

\subsection{The TBL development - the scope and content of reporting}

The creation of the TBL concept is rooted in a period where it was understood by all parties that focus was on Profit. But, also Profit had to some extent realised that there was a certain shift from shareholders to all stakeholders [3].

Sustainability Performance Management relies on that the TBL contains what is required in sustainability reporting and that the three dimensions can be reconciled. However, the first question is the scope or context of reporting. This leads to the question of how to delimit activities, presenting only what the company directly controls or presenting the entire supply chain or possibly the entire life cycle, which would mean including effects from buildings, installations, equipment and infrastructure built to support the value chain. The GRI guidelines suggest the use of the value chain as basis for reporting [9], but this is left open for the company to interpret. Companies that report on their value chain seem mostly to be those that have been pressured to do this by different stakeholders. For example, the clothes retailer H\&M could state that they only have control over their shops and that they do not have any production of their own and are therefore not liable for what happens with raw material and clothes production. Based on pressure from customers, watchdogs and the press, $\mathrm{H} \& \mathrm{M}$ has developed an elaborated system to track effects in its entire value chain [30]. This, however, still seems to be one of the exceptions. It could be argued that reporting should always be for both the area the company is directly responsible for but also for the entire value chain when it comes to key sustainability impacts. The conclusion is that one condition for the "what" to report is that the entire value chain with all its stakeholders is considered as is the intention in the GRI standards [9]. With focus on the entire value chain the next question is how to identify important impacts.

GRI recommends a materiality analysis to identify these using a scatter plot with effects on the TBL on the y-axis and the significance for the company on the x-axis [8]. Depending on the company view this could lead to comparing Profit issues with effects on Planet and People. With focus on People and Planet, materiality could possibly be reviewed by using the axes Planet and People. This is not further studied here, but left for future research.

In more recent reports the 17 SDGs are often been reviewed when defining materiality. The 17 goals are of varying types. Some define end stakeholder needs, such a Goal 1 "No Poverty" and Goal 13 "Fighting Climate Change" that links to one of the important planetary 
boundaries. Here it should be relatively easy for any organisation to assess its impact in the entire value chain. Such goals as 16 - "Peace, justice and strong institutions and" 17 "Partnership for the Goals" could be more difficult to relate to the company value chain. For any company the issue is to identify the most important impacts in the supply chain. To assess a company it could be argued that monitoring how the most important impact is managed should give an insight to the entire company sustainability management. If what is important is not managed well, then what is done with the rest does not matter that much. After having identified a set of important impacts the next challenge is to prioritise, including all the TBL dimensions.

There are no clear directives of how to compare different dimensions and therefore they are normally reported separately. Common problems in reporting are, providing absolute values that cannot be related to any context (national or branch) and that cannot be compared between each other. By using relative indicators different dimensions could be compared. Examples of this are such as earnings per tons of carbon dioxide emissions $\left(\mathrm{CO}_{2}\right)$.

Another problem with the TBL seems to be thinking that all three dimensions have to be ticked off. The airline SAS identifies climate as its main Planet challenge and also as its main challenge in the TBL [31]. With emissions of $4 \mathrm{Mtons} \mathrm{CO}_{2}$ per year this seems adequate. The main People challenges identified are gender equality and decent work. The topics are important, however the level of current performance in the Scandinavian company already should be world class. In the review the reader could easily get the impression that these social challenges are being at the level with the climate challenges, which they quite obviously are not. This highlights the issue of not only identifying the type of SDG goal but also assessing the current level of performance and thereafter setting priorities.

Integrated reporting is promoted by GRI as a way of mainstreaming sustainability reporting [32]. However, there could be a problem in that reports are made hard to read with large parts covering standard business reporting. It is questionable if general business reporting qualifies as sustainability reporting. Focus should maybe only be on what is done in addition to what is required by legislation, regulation, branch practice and budgets. Focus could also be on the stakeholder value created generally and in addition to shareholder value. There are few shareholders that are living in poverty and seen from a needs based perspective, shareholders and their profit maximisation are not important. Shareholder focus is still needed in order to produce an acceptable level of profit. This can be viewed in the category of what is required and therefore not as part of sustainability reporting. This would suggest that the current way of interpreting integrated reporting is not ideal.

\subsection{The planet dimension}

Climate is one of the nine Planetary Boundaries and one of the four where humanity already has crossed the safe limit [18]. Economic development tends to lead to higher carbon footprints and therefore there has been focus on decoupling - continuing to increase value but with a reduced footprint. It is difficult to envisage any business activity, especially when the entire value chain is considered, that does not have a carbon footprint. Since the ultimate goal for carbon emissions is to be carbon neutral or even carbon negative [29] it is logical to state that all companies need to manage their carbon footprint. Here, this should be seen as an example how of how other planetary limits could be worked with. 


\subsection{The people dimension}

The percentage of people living in absolute poverty has decreased but the group still consists of some 700 million people. The SDG 1 Sub-goal 1.1 is until 2030 to abolish extreme poverty defined as those that live with less than 1.25 US\$ per day. With a view of stakeholder value creation, companies could be rated on how well they contribute to this important goal. The links to poverty reduction might be less clear than links to carbon emissions, but by viewing the entire supply chain and its business idea it should be possible to study effects on poverty reduction, including potential but not realised possibilities to alleviate extreme poverty. Theoretically this links to the idea of the Bottom or Base of the Pyramid where poor people are seen both as a business opportunity and as a possible social contribution - focus on business ideas that benefit the poorest [33]. Examples are such as micro financing and selling products in very small units making prices low enough for the poorest.

\subsection{The profit dimension}

The system conditions defined by [21] would mean Planet is not subject to: I. increasing concentrations of substances extracted from the Earth's crust; II. increasing concentrations of substances produced by society; III. physical impoverishment by over-harvesting or other forms of ecosystem manipulation; and that IV, resources are used fairly and efficiently in order to meet basic human needs worldwide. This could seem as an impossible equation, but for the world not to live over its productive resources we probably need to go back to times before the dominating role of humans, where all these conditions, except possibly IV where being met. As a way towards sustainability focus on Creating Shared Value could be an option [25], [26]. Increasing resource scarcity could lead to more severe restrictions on "the license to operate" for those with low performance [27]. A paradigm shift seems to be needed. The current paradigm of business thinking - the current business as usual way - could be described as having focus on profit maximisation with some concern for People and Planet. The new paradigm would be to focus on maximised user value needs (People) compared to footprints (Planet). Profit would go to those that are best in this. This would require accepting strong sustainability, which can reverse the current global over consumption of resources.

\section{HOW COULD TBL PERFORMANCE BE MEASURED?}

This section describes the discussion on how to measure the TBL based on the examples of carbon emissions and poverty reduction.

\subsection{Carbon emissions benchmark}

There is, based on the Paris Agreement from 2015, a general acceptance of the goal of maximum $2{ }^{\circ} \mathrm{C}$ global temperature increase compared to preindustrial times. The rate of reduction is to some extent debated and could be based on the International Panel for Climate Change (IPCC) that uses probabilities of success for different scenarios. In the Carbon Law a critical view of the needs of change is reviewed with the conclusion that halving of the emissions is needed per each period of 10 years [29]. Still, according to [29] this is not enough, but by 2050 , there needs to be in place some technologies for large scale Carbon Capture and Storage. The Planet goal for carbon emissions in 2030 is set based on the Carbon Law using 2010 as year of reference. The reason is that the Carbon Law represents a more recent and critical review. This means that the benchmark sustainable change for companies is a $75 \%$ reduction of carbon emissions from 2010 to 2030 . This is calculated as the relative performance in both sales value per carbon footprint and in user value per carbon footprint. 
The absolute level of emissions is important, but a company which has a better relative performance as value per carbon footprint could increase its market share which could lead to a lower level of carbon emission reductions. However, the branch in which the company is working should reduce its total emissions according to the plan.

\subsection{Extreme poverty benchmark}

With focus on survival of People the main stakeholder value produced could be assessed as fraction of sales value, which is directly or indirectly converted to user value for those in absolute poverty. This means that the business idea becomes critical and that business ideas targeting higher levels of the Maslow hierarchy of needs will be penalised. The justification is that this could be seen as supporting risk management. Lack of resources could steer production towards what is needed by regulations or by taxes on "luxury" products. In practical terms this means that a non-necessary product needs to have a higher ratio for sales compared to footprints. Assessing the business end effect on those living in absolute poverty could be challenging but should be doable.

\subsection{Eco-efficiency and people value per planet harm}

The WBCSD promotes the relative indicator Eco-Efficiency. The description is that "ecoefficiency brings together the two eco-dimensions of economy and ecology to relate product or service value to environmental influence" [24]. However, what counts is the user needs value being serviced, e.g. as the contribution to reduce the number of those living in extreme poverty. Sales value could still be used as an additional estimate of user value produced. In terms of Eco-Efficiency this would mean reporting the sales value compared to different footprints e.g. the carbon footprint. The world GNP could be compared with the world total carbon emissions to have an idea of what the average value creation is. An estimate of this is about $2500 \mathrm{US} \$$ /ton of $\mathrm{CO}_{2}$ [27]. With the needs of simultaneous economic development and reduction of carbon emissions the "carbon productivity" needs to increase. Companies with business ideas focusing on "luxury" products would probably need to focus on higher value addition in anticipation of taxes or reduction requirements for carbon emissions. The proposed value per harm indicator for the two chosen KPIs could be expressed as reduction of extreme poverty compared to carbon emissions. This would imply focus on what could be seen as some of the vital few impacts to focus on.

\subsection{Proposed visionary TBL with proposed indicators}

In Table 1 a proposed visionary definition for the TBL is presented using the examples of Climate Change and Extreme Poverty.

Table 1 should be seen as a first iteration with proposed targets for change seen as suggestions and examples. In this simplified review only two impacts, chosen based on a Pareto-reasoning, have been considered. The proposed target for carbon productivity in 2030 is based both on a targeted reduction of carbon emissions and on a doubling of the value added from 2015.

The presentation in Table is a visualisation of a new paradigm where focus is on living up to the Brundtland commission definition of seeing that People satisfy their needs without reducing the possibilities for the future generations. Those organisations that do this in the best way will be profitable. This means a shift from the old paradigm where Profit is seen as a value in itself towards a paradigm where focus is on People and Planet. This resembles the strategy from Quality Management of customer needs focus as a way of being profitable with 
the difference that customers have been extended to stakeholders. It is also important to note that focus is on stakeholder needs and not primarily on stakeholder wants.

The proposed targets in Table 1 are indicative. For the carbon reduction the Carbon Law has been used [29]. The money needed to combat extreme poverty has not been assessed. This will also depend on the target level, which probably should be above the minimum level of $1.25 \mathrm{US} \$$ /day. Carbon productivity is here defined as sales value per carbon footprint in

Table 1: Proposed visionary Triple Bottom Line with proposed indicators.

\begin{tabular}{|c|c|c|c|c|}
\hline $\begin{array}{l}\text { TBL } \\
\text { dimensions }\end{array}$ & Position & Rate & KPI & Comments \\
\hline Planet & $\begin{array}{l}\text { Reduction of } \\
\text { carbon emissions } \\
\text { with } 75 \% \text { from } \\
2010 \text { until } 2030 \\
\text { for company } \\
\text { processes and for } \\
\text { the main value } \\
\text { chain }\end{array}$ & $\begin{array}{l}\text { Halving of } \\
\text { carbon emissions } \\
\text { per } 10 \text {-year } \\
\text { period for } \\
\text { company } \\
\text { processes and for } \\
\text { the main value } \\
\text { chain }\end{array}$ & $\begin{array}{l}\text { Tons of } \mathrm{CO}_{2} \text {-e/ } \\
\text { year; } \\
\text { Reduction rate } \% \\
\text { per year }\end{array}$ & $\begin{array}{l}\text { Most companies } \\
\text { have carbon } \\
\text { footprints, but } \\
\text { there could also } \\
\text { be negative } \\
\text { footprints } \\
\text { indicating that } \\
\text { the business is } \\
\text { about reducing } \\
\text { carbon emissions }\end{array}$ \\
\hline People & $\begin{array}{l}\text { Providing } \\
\text { economic benefits } \\
\text { to those in extreme } \\
\text { poverty }\end{array}$ & $\begin{array}{l}\text { Increasing } \\
\text { contribution }\end{array}$ & $\begin{array}{l}\% \text { of sales value } \\
\text { converted into } \\
\text { user needs value } \\
\text { for the poor. } \\
\text { Monetary value } \\
\text { for combating } \\
\text { extreme poverty } \\
\% \text { of yearly } \\
\text { change }\end{array}$ & \begin{tabular}{|l} 
Exact values \\
from a need base \\
could be \\
calculated based \\
on bringing \\
everybody to a \\
target level \\
above 1.25 \\
US\$/day.
\end{tabular} \\
\hline Profit & $\begin{array}{l}\text { Company results } \\
\text { for sales; } \\
\text { For value created } \\
\text { for those in } \\
\text { extreme poverty }\end{array}$ & $\begin{array}{l}\text { Increasing effect } \\
\text { on poverty } \\
\text { reduction }\end{array}$ & $\begin{array}{l}\text { User value for } \\
\text { those in extreme } \\
\text { poverty } \\
\text { converted into } \\
\text { US\$ }\end{array}$ & $\begin{array}{l}\text { Exact figures to } \\
\text { be assessed. }\end{array}$ \\
\hline Profit/Planet & $\begin{array}{l}\text { Sales carbon } \\
\text { productivity }\end{array}$ & $\begin{array}{l}\text { Increasing } \\
\text { carbon } \\
\text { productivity - } \\
\text { doubling it every } \\
5 \text { years (starting } \\
2015) \\
\end{array}$ & $\begin{array}{l}\mathrm{US} \$ / \text { ton } \mathrm{CO}_{2} \text {-e } \\
\text { Change in } \% \text { per } \\
\text { year. }\end{array}$ & $\begin{array}{l}\text { A tentative } \\
\text { benchmark for } \\
2030 \text { would be } \\
\text { about } 20000 \\
\text { US\$/ton } \mathrm{CO}_{2} \text {-e } \\
\text { (ref) }\end{array}$ \\
\hline $\begin{array}{l}\text { User value/ } \\
\text { Planet }\end{array}$ & $\begin{array}{l}\text { Value for the poor } \\
\text { per carbon } \\
\text { footprint }\end{array}$ & $\begin{array}{l}\text { Increasing the } \\
\text { value/harm } \\
\text { doubling it every } \\
10 \text { years }\end{array}$ & $\begin{array}{l}\text { US\$-value for } \\
\text { the poor/ton } \\
\mathrm{CO}_{2} \text {-e } \\
\text { Change in \% per } \\
\text { year. }\end{array}$ & $\begin{array}{l}\text { Indicative figures } \\
\text { to be assessed. }\end{array}$ \\
\hline
\end{tabular}


the entire value chain. The proposed rate of change should mainly be seen as an example. The proposed targets are for 2030 and include both the expected level to be achieved and the continued rate of change.

\section{DISCUSSION AND CONCLUSIONS}

In this section the results from Sections 3 and 4 are discussed.

\subsection{Limitations in the study}

The work is mainly conceptual and ideas based on the literature review needs to be strengthened. However, the idea of seeing sustainability as a stable state where People and Planet needs are not compromised is seen to be in accordance with the system conditions of the Natural Step [21] and with the Brundtland commission definition of sustainable development.

The value chain has been used for defining the scope. It has not been discussed if instead the Life Cycle should be used. For some businesses with heavy investments like for buildings this could lead to substantial differences. However, this discussion is left for further research.

The presented results are based on the assumptions that it is possible to single out some vital impacts that can be used as indicators for sustainability reporting. The logic is that if what is important is not properly reported then the rest does not matter.

In Planet dimension the focus on reducing the footprint excludes the possibility that the company produces a negative footprint. This could be the case e.g. for a company working with Carbon Capture and Storage. Theoretically this means that the unit of Planet Value has to be included when reviewing the business results. To create Planet value seems still to be relatively rare, when studying major companies and the conclusion is that as a start for evaluation focus on Planet Harm is relevant. With increasing costs for carbon emissions and with expectations of increased carbon productivity, CCS could become a viable business idea. Still, it goes against quality principles of working with root causes and it goes against the idea of the circular economy. The issue of climate compensation and how to account for this has not been discussed.

The proposed visionary situation described in Table 1 only serves as an example. Values for carbon levels and rate of emission reduction is based on literature whereas the value creation for the those living in extreme poverty is only indicative with some assumed rates of change only.

\subsection{Future research}

The next step in future research is to convert Table 1 into an assessment matrix that can be used to categorise company positions based on their sustainability reports. The matrix should be able to position companies as in the business as usual matrix with focus on profit, in transition or in the new paradigm of focus on People and Planet.

Materiality analyses might have to be redesigned to focus on People and Planet compared to the current practise of comparing the entire TBL with company interest. This would highlight the primary role of working for People and Planet. Focus areas would be highlighted both as lack of value added to those needing it and as footprints.

\section{CONCLUSIONS}

The answers to the first research questions of: "How could visionary performance levels of Profit, People and Planet be described based on stakeholder focus needs?" are based on the 
main conclusion that a paradigm shift is needed from focus on Profit as an end value to focus on People and Planet. Success in working for People and Planet will result in Profit. There is a parallel with a quality focus strategy where profit is to be achieved by focusing on customer needs. When going from Quality to Sustainability the focus shifts from customers to stakeholders. The main stakeholders identified are Planet and People. The stakeholder needs and company footprints are studied in the entire value chain. This is comparable of looking at costs with the addition that footprints should also be counted after sales until the end of life or recycling of the product.

Value adding opportunities, as exemplified with the ideas of the Based of the Pyramid [33] should be considered when developing the business idea. There could be opportunities in alleviating poverty. Not doing this, when there is a business opportunity, could be seen as non-sustainable use of resources.

To demonstrate how visions could be created, the main Planet and People needs have been identified as limiting carbon emissions and eradicating extreme poverty corresponding to the SDGs $\mathrm{nr} 13$ and 1 respectively. In Table 1 the visionary position in 2030 has been proposed for the two chosen impacts.

It is argued that priorities should be set based on the most important Planet and People needs, which means that in some cases only the Planet or only People issues should be in focus.

It is suggested that the current proposed practise of where sustainability reporting is integrated in business reporting is not suitable. Standard business reporting is not seen as sustainability reporting. With the redefinition of Profit from sales value to stakeholder value only, the creation of stakeholder value should be included in sustainability reporting as part of Profit.

The main answers for the second research question of "How could TBL performance be measured?" are, using absolute and relative indicators focusing on the vital few impacts. Based on the examples used of the SDGs of "Climate Action-No 13" and "Eradicating Extreme Poverty-No 1". The proposed absolute indicators are yearly tons of $\mathrm{CO}_{2}$ emitted, total value of sales and value delivered to those living in extreme poverty in US\$. The relative indicators are sales in US\$/ton per ton of $\mathrm{CO}_{2}$ and value in US\$ created for those in extreme poverty/ton of $\mathrm{CO}_{2}$. These indicators are then measured and compared to externally set and need based targets based on e.g. the Planetary Boundaries [18] and the UN Sustainable Development Goals, see Table 1.

\section{REFERENCES}

[1] Global Footprint Network, Earth Overshoot Day. Online. www.overshootday.org. Accessed on: 8 June 2018.

[2] Elkington, J., Towards the sustainable corporation: Win-win-win business strategies for sustainable development. California Management Review, 36(2), pp. 90-100, 1994. DOI: $10.2307 / 41165746$.

[3] Elkington, J., Partnerships from cannibals with forks: The triple bottom line of 21stcentury business. Environmental Quality Management, 8(1), pp. 37-51, 1998. DOI: 10.1002/tqem.3310080106.

[4] Elkington, J., Accounting for the triple bottom line. Measuring Business Excellence, 2(3), pp. 18-22, 1998. DOI: 10.1108/eb025539.

[5] Global Reporting Initiative, Reporting Standards. Online. www.globalreporting.org/ standards. Accessed on: 8 Jun. 2018. 
[6] Isaksson R., Economic sustainability and the cost of poor quality. Corporate Social Responsibility and Environmental Management, 12(4), pp. 197-209, 2005. DOI: 10.1002/csr.85.

[7] Hubbard, G., Measuring organizational performance: Beyond the triple bottom line. Business Strategy and the Environment, 18(3), pp. 177-191, 2009. DOI: 10.1002/bse.564.

[8] Global Reporting Initiative, GRI 101 Foundation: 2016 - Materiality, p. 10. Online. www.globalreporting.org/standards. Accessed on: 8 Jun. 2018.

[9] Global Reporting Initiative, GRI 101 Foundation: 2016 - Sustainability Context, p. 9. Online. www.globalreporting.org/standards. Accessed on: 8 Jun. 2018.

[10] Coca Cola EP, Stakeholder Progress Report 2016 - water footprint, p. 12. Online. www.ccep.com/pages/downloads-centre. Accessed on: 1 Feb. 2018.

[11] Coop Yearly Report 2016 (in Swedish), p. 45. Online. www.coop.se/contentassets/1f57d8d51cb9477a9ec8a01d5641479a/coop-arsrapportar-2016.pdf. Accessed on: 8 Jun. 2018.

[12] Carter, C.R. \& Rogers, D.S., A framework of sustainable supply chain management: moving toward new theory. International Journal of Physical Distribution \& Logistics Management, 38(5), pp. 360-387, 2008. DOI: 10.1108/09600030810882816.

[13] Hall, T.J., The triple bottom line: What is it and how does it work? Indiana Business Review, 86(1), pp. 4-8, 2011.

[14] Rambaud, A. \& Richard, J., The "Triple Depreciation Line" instead of the "Triple Bottom Line": Towards a genuine integrated reporting. Critical Perspectives on Accounting, 33, pp. 92-116, 2015. DOI: 10.1016/j.cpa.2015.01.012.

[15] Milne, M.J. \& Gray, R., W(h)ither ecology? The triple bottom line, the global reporting initiative, and corporate sustainability reporting. Journal of Business Ethics, 118(1), pp. 13-29, 2013. DOI: 10.1007/s10551-012-1543-8.

[16] Norman, W. \& MacDonald, C., Getting to the bottom of "triple bottom line". Business Ethics Quarterly, 14(2), pp. 243-262, 2004.

[17] Jamali, D., Insights into triple bottom line integration from a learning organization perspective. Business Process Management Journal, 12(6), pp. 809-821, 2006.

[18] Rockström, J. et al., Planetary boundaries: Exploring the safe operating space for humanity. Ecology and Society, 14(2), 2009.

[19] Science Based Targets. Online. http://sciencebasedtargets.org. Accessed on: 8 Jun. 2018.

[20] Haffar, M. \& Searcy, C., Target-setting for ecological resilience: Are companies setting environmental sustainability targets in line with planetary thresholds? Business Strategy and the Environment, 2017.

[21] Robèrt, K.H., Tools and concepts for sustainable development, how do they relate to a general framework for sustainable development, and to each other? Journal of Cleaner Production, 8(3), pp. 243-254, 2000. DOI: 10.1016/s0959-6526(00)00011-1.

[22] Broman, G.I., \& Robèrt, K.H., A framework for strategic sustainable development. Journal of Cleaner Production, 140, pp. 17-31, 2017. DOI: 10.1016/ j.jclepro.2015.10.121.

[23] Rogers, K. \& Hudson, B., The triple bottom line - The synergies of transformative perceptions and practices for sustainability, Od Practitioner, 43(4), pp. 3-9, 2011.

[24] Verfaillie, H.A., \& Bidwell, R., Measuring Eco-Efficiency: A Guide to Reporting Company Performance. World Business Council for Sustainable Development, 2000. 
[25] Porter, M.E. \& Kramer, M.R., Strategy and society: The link between corporate social responsibility and competitive advantage. Harvard Business Review, 84(12), pp. 7892, 2006.

[26] Porter, M.E. \& Kramer, M.R., The big idea: Creating shared value. Harvard Business Review, 89(1), pp. 62-77, 2011.

[27] Isaksson, R.B., Garvare, R., \& Johnson, M., The crippled bottom line-measuring and managing sustainability. International Journal of Productivity and Performance Management, 64(3), pp. 334-355, 2015.

[28] Upward, A. \& Jones, P., An ontology for strongly sustainable business models: Defining an enterprise framework compatible with natural and social science. Organization \& Environment, 29(1), pp. 97-123, 2016.

[29] Rockström, J., Gaffney, O., Rogelj, J., Meinshausen, M., Nakicenovic, N. \& Schellnhuber, H.J., A roadmap for rapid decarbonization. Science, 355(6331), pp. 1269-1271, 2017.

[30] H\&M Sustainability Report 2017. Online. https://about.hm.com/content/dam/ hmgroup/groupsite/documents/masterlanguage/CSR/reports/2017\%20Sustainability \%20report/HM_group_SustainabilityReport_2017_FullReport.pdf. Accessed on: 8 Jun. 2018.

[31] SAS Sustainability Report 2016/2017. Online. www.sasgroup.net/en/sassustainability-report-2016-2017/. Accessed on: 8 Jun. 2018.

[32] GRI Integrated Reporting. Online. www.globalreporting.org/information/currentpriorities/integrated-reporting/Pages/default.aspx. Accessed on: 8 Jun. 2018.

[33] Prahalad, C.K., Bottom of the pyramid as a source of breakthrough innovations. Journal of Product Innovation Management, 29(1), pp. 6-12, 2012. DOI: 10.1111/j.1540-5885.2011.00874.x. 